\title{
Effect of Eugenol-Based Endodontic Cement on the Adhesion of Intraradicular Posts
}

\author{
Edson ALFREDO \\ Emanuel Soares de SOUZA \\ Melissa Andréia MARCHESAN \\ Silvana Maria PAULINO \\ Ricardo GARIBA-SILVA \\ Manoel Damião SOUSA-NETO
}

Department of Dentistry, University of Ribeirão Preto, Ribeirão Preto, SP, Brazil

\begin{abstract}
The present study evaluated, in vitro, the influence of an eugenol-based endodontic sealer (EndoFill) on the adhesion of intra-radicular posts cemented with a resin-based cement (Enforce) ou a zinc phosphate cement. Twenty-four single-rooted maxillary canines were divided into 2 groups $(\mathrm{n}=12)$ and obturated with either gutta-percha points plus EndoFill or gutta-percha points alone (no cement). In each group, half of intracanal posts $(n=6)$ were cemented with Enforce resin-based cement and half with zinc phosphate cement. Specimens were submitted to pull-out test in an Instron machine and tensile force was applied at a crosshead speed of $0.5 \mathrm{~mm} / \mathrm{min}$ until post dislodgement. The maximum forces required for post removal was recorded $(\mathrm{N})$ and means were submitted to statistical analysis by Kruskal-Wallis test $(\mathrm{p}<0.01)$. Posts cemented with zinc phosphate cement were significantly more retentive $(353.4 \mathrm{~N})$ than those cemented with Enforce $(134.9 \mathrm{~N})(\mathrm{p}<0.01)$. Regarding the influence of the eugenol-based cement (EndoFill) on post retention, there was statistically significant difference $(\mathrm{p}<0.01)$ only between the groups cemented with Enforce, i.e., in the canals filled with EndoFill + guta-percha there was lower bond strength than in the canals filled with gutta-percha points alone (101.5 and $168.2 \mathrm{~N}$, respectively). In conclusion, the zinc-phosphate-based cement showed greater post retention than the resin-based cement. The findings of this study suggest that the eugenol-containing sealer interfered with the adhesive properties of the resin-based cement.
\end{abstract}

Key Words: intraradicular posts, eugenol-based endodontic cement, resin-based cement.

\section{INTRODUCTION}

After endodontic therapy, the tooth must return to normal function. However, when a great amount of dental substance is lost, the placement of an intraradicular post is required before cementation of the prosthetic crown. In addition to increasing the retention of coronal restorations, the post also prevents the leakage of microrganisms or organic fluids from the oral cavity into the root canal system (1-3).

Retention is of high importance for the use of intracanal posts in endodontically treated teeth (4). Standlee et al. (5) showed that post retention is increased when using long posts rather than short posts, rough walls rather than smooth walls and parallel rather than conical. Other studies (6) showed that threaded (active) posts are more retentive than passive posts. The capacity of different cements to retain posts is related to mechanical properties, adhesion capacity to metal and dentin and durability (7). Several procedures, including placement of intraradicular posts, are required by indirect restorative technique and involve use of cements for bonding to the remaining tooth structure. Cementing is defined as the use of a moldable substance for sealing or cementing two parts, providing retention, filling spaces and reducing microleakage (8).

The use of resin-based cements has been recommended to improve retention of posts in endodontically treated teeth (9). Goldman et al. (10) found high retention values for resin-based cements in comparison to zinc phosphate and glass ionomer cements. Similar results have been observed by other authors $(7,11)$. The combination of dentin bonding agents and resin-based cements has been shown to increase retention (12).

Correspondence: Prof. Dr. Manoel Damião Sousa-Neto, Rua Célia de Oliveira Meireles, 350, Jd. Canadá, 14024-070 Ribeirão Preto, SP, Brasil. Tel: +55-16-3623-6002. Fax: +55-16-603-6783. e-mail: sousanet@unaerp.br 
On the other hand, few studies have addressed the effects of endodontic sealers and their components on post retention. Substantial loss of retention has been reported when eugenol was used with resin-based cement because eugenol has deleterious effects on resin compounds $(11,13)$. Another study (14) found that a long interval between root canal obturation with zincoxide-based cements and post placement has a negative influence on retention, probably due to the greater penetration of eugenol into the dentinal tubules.

Considering that zinc oxide and eugenol-based cements are the most widely used by endodontists worldwide, this study evaluated in vitro the influence of an eugenol-based root canal sealer (EndoFill) on the adhesion of intraradicular posts cemented with either Enforce resin-based cement or zinc phosphate cement.

\section{MATERIAL AND METHODS}

Twenty-four human maxillary canines were selected from laboratory stock according to shape and length of their roots: straight, with no pronounced flatness (mesiodistal or buccolingual) and one root canal. The teeth were washed in water for $24 \mathrm{~h}$ and kept in distilled water until use. The crowns were sectioned transversally close to the cementoenamel junction and discarded. The roots (15-mm long) were embedded in acrylic resin using aluminum tubes (Orto Clas; Clássico, São Paulo, SP, Brazil) and stored in saline.

Root canals were instrumented to a working length of $14 \mathrm{~mm}$ (1 mm short of the apex) up to a \#50 K-file (Dentsply/Maillefer, Ballaigues, Switzerland) according to the crown-down technique. During instrumentation, the canals were irrigated with $2 \mathrm{~mL} 1 \%$ sodium hypochlorite at every change of files. The specimens were randomly assigned to 2 groups $(n=12)$ and obturated with either gutta-percha points plus EndoFill eugenol-based sealer (Dentsply Ind. e Com., Petrópolis, RJ, Brazil) or gutta-percha points alone (no cement) using the lateral condensation technique.

Canal entrance of all roots was sealed with a temporary material (Coltosol; Vigodent, Rio de Janeiro, RJ, Brazil) for $72 \mathrm{~h}$ until cement hardening. Root canals were further prepared for dowel impression with \#6 Largo burs ( $9 \mathrm{~mm}$ long; $1.7 \mathrm{~mm}$ diameter) (Dentsply/ Maillefer). Because Largo burs have a conical end and the posts should be cylindrical, the penetration guide of the burs was removed and a stopper was positioned at their active tip to delimit an 8-mm length. Cylindrical post spaces were prepared with a low-speed handpiece attached to a parallelometer to obtain vertical preparations with standard diameters and dentin walls parallel to the long axis of the roots.

Post pattern was fabricated using the direct molding technique with chemically active acrylic resin (Duralay; Reliance Dental, Worth, IL, USA). A 5-mmlong cylindrical core was fabricated with the same diameter as that of the intracanal portion. A wax ring with diameter of $8 \mathrm{~mm}$ was fixed to the core for application of the forces during the test.

The patterns were cast in copper-aluminum alloy (Goldent L.A. Com. Imp. Exp., São Paulo, SP, Brazil), according to the manufacturers' instructions. The cast posts were cleaned, washed in running water and blasted using an aluminum-oxide air abrasion device (Bio-art, São Carlos, SP, Brazil) with the following parameter settings: $250-\mu \mathrm{m}$ particle size, distance of 20 $\mathrm{mm}$ and 20-s blasting time. The cast specimens had an 8-mm long intracanal portion (post), a 5-mm long coronal portion (core) and an 8-mm-diameter ring attached to the core (Fig. 1).

In each group, half of posts $(n=6)$ were cemented with Enforce resin-based cement (Dentsply Ind. e Com. Ltda) and half were cemented with zinc phosphate cement (LS; Vigodent). Enforce cement was used according to the manufacturer's instructions. Intracanal dentin was etched with Dental Gel (phosphoric acid, water, colloid silica and inorganic dye) for 15 s. A thin, uniform cement layer was applied to post surface and root canal and the post-core setting was seated into the post space preparation, kept under digital pressure for $1 \mathrm{~min}$ and excess material was removed

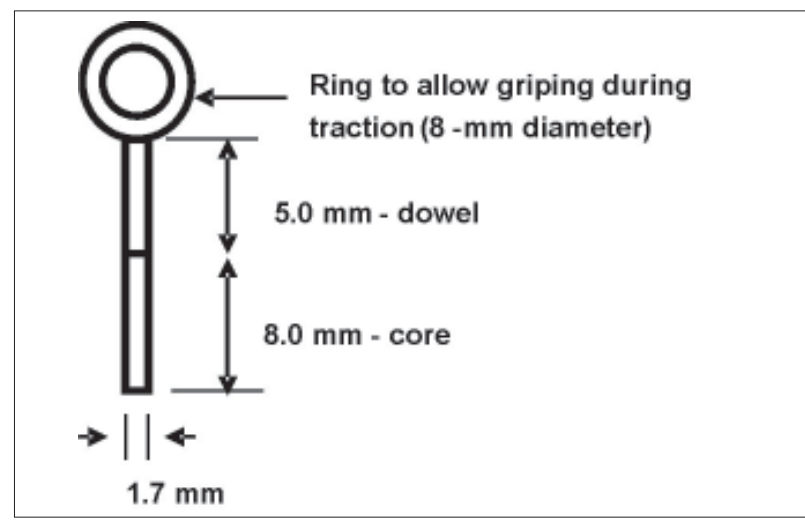

Figure 1. Schematic drawing of the post-core setting configuration. 
from the margins with a disposable brush. Lightactivation (Ultralux Eletronic; Dabi Atlante, Ribeirão Preto, SP, Brazil) of the resin-based cement was done for $20 \mathrm{~s}$ at each surface of the core (buccal, palatal, mesial and distal). The roots were left undisturbed for 6 min to allow self-curing of the cement inside the canal.

Zinc phosphate cement was also used according to the manufacturer's instructions. A thin, uniform cement layer was applied to post surface and root canal and the post-core setting was adapted to the prosthetic space and kept under digital pressure for $1 \mathrm{~min}$. Excess cement was removed with an explorer.

Specimens were stored in distilled water at $37^{\circ} \mathrm{C}$ for $72 \mathrm{~h}$ and then submitted to tensile bond strength testing. The roots were individually attached to a custom device to be held secure in a vertical position and minimize the incidence of non-axial forces, so that traction forces could be applied parallel to their long axis. The ring fixed to the core was grasped by the clamping apparatus in an Instron machine (model 4444; Instron Corporation, Canton, MA, USA) running at a crosshead speed of $0.5 \mathrm{~mm} / \mathrm{min}$ until dislodgement of the post from the root (15). Maximum force required for post removal was recorded $(\mathrm{N})$ for each specimen and means were calculated and analyzed statistically by Kruskal-Wallis test at 0.01 significance level.

\section{RESULTS}

Bond strength means required for dislodging the posts from the roots in Table1.

Posts cemented with zinc phosphate cement were significantly more retentive $(353.4 \mathrm{~N})$ than those cemented with Enforce $(134.9 \mathrm{~N})(\mathrm{p}<0.01)$. Regarding

Table 1. Bond strength means $(\mathrm{N})$ required for dislodging the posts from the root canals combining different endodontic sealers and luting agents.

\begin{tabular}{llll}
\hline Cements & \multicolumn{2}{c}{ Endodontic fillings } & Means \pm SD \\
\cline { 2 - 3 } & $\begin{array}{c}\text { Endo Fill }+ \\
\text { gutta-percha }\end{array}$ & $\begin{array}{c}\text { Gutta-percha } \\
\text { (no cement) }\end{array}$ & \\
\hline Enforce & $101.5 \pm 17.5 \mathrm{a}$ & $168.2 \pm 66.8 \mathrm{c}$ & $134.9 \pm 58.1$ \\
Zinc phosphate & $364.5 \pm 53.3 \mathrm{~b}$ & $342.4 \pm 80.3 \mathrm{~b}$ & $353.4 \pm 66.0$
\end{tabular}

Different letters indicate statistically significant difference $(p<0.01)$ between the luting agents. the influence of the eugenol-based cement (EndoFill) on post retention, there was statistically significant difference $(p<0.01)$ only between the groups cemented with Enforce, i.e., in the canals filled with EndoFill + gutapercha there was lower bond strength than in the canals filled with gutta-percha points alone (101.5 and 168.2 $\mathrm{N}$, respectively).

\section{DISCUSSION}

Recent endodontic therapy has shown high success rates. However, several clinical situations require great dentin removal and crown involvement for adequate access and effective preparation of root canals. In these cases, as well as in other cases where crown destruction is present, the placement of a prosthetic crown for tooth rehabilitation should be preceded by cementation of intraradicular posts to increase crown retention to the remaining tooth structure.

The major factors affecting post retention are their dimensions (length, diameter), shape (conical, cylindrical), type of surface (serrated, screw, smooth), intracanal space preparation, type of cement and operator skills $(5,16)$. It has been advocated that intraradicular posts should have at least the same length as the future post-retained crown $(16,17)$. Retention would be improved when the post is longer than the coronal portion and occupies up to $2 / 3$ of the total root length. At least 3-5 $\mathrm{mm}$ of filling material should be left in the apical third to prevent post displacement and subsequent microleakage at dentin/cement/dowel interface.

In this study, all procedures were performed by a single operator. All factors regarding the posts were kept constant and only the type of root canal filling material and the post luting agent was varied.The load required for dislodgment of posts cemented with zinc phosphate was significantly higher $(353.4 \mathrm{~N})$ than that required for posts cemented with Enforce (134.9 N), as observed by Schwartz et al. (9). This is possibly due to the fact that EndoFill contains eugenol, which could have affected the adhesiveness of the resin-based cement. These results are consistent with those of previous studies $(11,13)$, which found that resin-based cements should not be used with eugenol-containing materials because the phenolic components of eugenol interfere with resin curing. Additionally, Hagge et al. (14) observed that an increase in the interval between root canal filling with zinc oxide-based cement and post 
placement affects retention negatively, probably due to the greater penetration of eugenol into dentinal tubules. Adhesive resin-based cements contain 4methylacrylate-ethyl-trimethyl-anhidride that reacts chemically with the oxide metallic layer increasing post retention compared to non-adhesive resin cements. Several studies (18-20) showed that posts cemented with Panavia adhesive resin cement were more retentive than those cemented with zinc phosphate. In this study, the posts cemented with Enforce were less retentive, probably because this is not an adhesive cement.

When zinc phosphate was used as a luting agent, no statistically significant difference $(\mathrm{p}>0.01)$ was found between the groups filled with and without eugenolbased sealer (respectively $364.5 \mathrm{~N}$ and $342.4 \mathrm{~N}$ ). Therefore, the eugenol-containing sealer (Endofill) did not interfere with the properties of the zinc phosphate cement, which yielded higher bond strength means.

In conclusion, the zinc-phosphate-based cement showed greater post retention than the resinbased cement. The findings of this study suggest that the eugenol-containing sealer interfered with the adhesive properties of the resin-based cement.

\section{RESUMO}

No presente estudo avaliou-se, in vitro, a influência do cimento endodôntico à base de óxido de zinco e eugenol (EndoFill) na adesão de pinos intra-radiculares cimentados com cimento resinoso (Enforce) ou cimento fosfato de zinco. Vinte e quatro caninos superiores uniradiculares foram distribuídos em dois grupos e obturados com cimento a base de oxido de zinco e eugenol + cones de guta-percha ou somente cones de guta-percha (sem cimento). Em metade dos espécimes em cada grupo $(n=6)$, os pinos intra-radiculares foram cimentados com cimento resinoso Enforce e na outra metade com cimento de fosfato de zinco. Os espécimes foram submetidos a ensaios de resistência à tração numa máquina Instron 4444, sendo os valores de força máxima necessária ao desprendimento dos retentores registrados e submetidos à análise estatística pelo teste de Kruskal-Wallis $(\mathrm{p}<0,01)$. Os pinos cimentos com cimento fosfato de zinco apresentaram valor médio de resistência à tração superior $(353,4$ N) ao dos pinos cimentados com Enforce (134,9 N). Em relação à influência do cimento à base de eugenol na retenção dos pinos intra-radiculares, houve diferença significante $(p<0,01)$ somente entre os grupos cimentados com Enforce, sendo que nos canais obturados com EndoFill + guta-percha houve menor resistência à tração que nos canais obturados apenas com guta-percha (respectivamente 101,5 e 168,2 N). Conclui-se que o cimento à base de fosfato de zinco apresentou maior retenção que o cimento resinoso Enforce e que o cimento obturador contendo eugenol (EndoFill) somente afetou as propriedades adesivas do cimento resinoso.

\section{REFERENCES}

1. Batern G, Ricketts DNJ, Saunders WP. Fiber-based post systems: a review. Br Dent J 2003;195:43-48.

2. Gallo JR, Miller T, Xu X, Burgess JO. In vitro evaluation of the retention of composite fiber and stainless steel posts. J Prosthodont 2002;11:25-29.

3. Schwartz RS, Robbins JW. Post placement and restoration of endodontically treated teeth: A literature review. J Endod 2004;30:289-301.

4. Robins JW. Guidelines for the restoration of endodontically treated teeth. J Amer Dent Assoc 1990;120:558-566.

5. Standlee JP, Caputo AA, Hanson EC. Retention of endodontic dowels: effects on cement, dowel length, diameter, design. J Prosthet Dent 1978;39:401-405.

6. Standlee JP, Caputo AA. Endodontic dowel retention with resinous cements. J Prosthet Dent 1992;68:913-917.

7. Chan FW, Harcourt JK, Brockhurst PJ. The effect of post adaptation in the root canal on retention of posts cemented with various cements. Aust Dent J 1993;38:39-45.

8. Phillips RW. Skinner's science of dental materials, 10th ed. Philadelphia: WB Saunders; 1996.

9. Schwartz RS, Murchison DF, Walker WA. Effects of eugenol and non eugenol endodontic sealer cements on post retention. J Endod 1998;24:564-567.

10. Goldman M, Devitre R, Pier M. Effect of dentin smeared layer on tensile strength of cemented posts. J Prosthet Dent 1984;52:485-488.

11. Tjan AHL, Nemetz H. Effect of eugenol containing endodontic sealer on retention of prefabricated posts luted with an adhesive composite resin cement. Quintessence Int 1992;23:839-844.

12. Liberman R, Bem-Amar A, Urstein M, Gontar G, Fitzig S. Conditioning of root canals prior to dowel cementation with composite luting cement and two dentine adhesive systems. J Oral Rehabil 1989;16:597-602.

13. Hagge MS, Wong RDM, Lindemuth JS. Effect of three root canal sealers on the retentive strength of endodontic post luted with a resin cement. Int Endod J 2002;35:372-378.

14. Hagge MS, Wong RDM, Lindemuth JS. Retention, of posts luted with phosphate monomer-based composite cement in canals obturated using a eugenol sealer. Am J Dent 2002;15:378-382.

15. Alfredo E, Carvalho-Junior JR, Silva-Sousa YT, CorrerSobrinho L, Saquy PC, Sousa-Neto MD. Evaluation of retention of post-core system cemented with different materials on dentine surfaces treated with EDTA or Er: YAG laser irradiation. Photomed Laser Surg 2005;23:36-40.

16. Shillingburg HT, Kessler JC. Restoration of the endodontically treated tooth. Chicago: Quintessence Publishing Co.; 1982.

17. Johnson JK, Sakumura JS. Dowel form and tensile force. J Prosthet Dent 1978;40:645-649.

18. Love RM, Purton DG. Retention of posts with resin, glass ionomer and hybrid cements. J Dent 1998;26:599-602.

19. Junge T, Nicholls JI, Phillips KM, Libman WJ. Load fatigue of compromised teeth: a comparison of 3 luting cements. Int J Prosthodont 1998;11:558-564.

20. Mitchell CA. Selection of materials for post cementation. Dent Update 2000;27:350-354.

Accepted January 11, 2006 